DOI: https://doi.org/10.31392/NZ-npu-145.2019.02

УДК 371.134:373

Бузоверя А. Г.

\title{
АНАЛІЗ РЕЗУЛЬТАТІВ ЕТАПНОГО КОНТРОЛЮ ОЦІНКИ РІВНЯ ТЕХНІЧНОЇ ПІДГОТОВЛЕНОСТІ ЧЕРЛІДИРІВ-ФЛАЄРІВ ПІСЛЯ ВПРОВАДЖЕННЯ ЕКСПЕРИМЕНТАЛЬНОЇ МЕТОДИКИ
}

Дослідження рівня технічної підготовленості черлідирів-флаєрів визначався за підібраними нами контрольними тестами, які були об'єднані в чотири групи комплексних критеріїв: базові рухи черлідингу, чер-стрибки, складність положень флаєра, технічне виконання акробатичних елементів. В свою чергу дані комплекси містили у собі наступні тести: “комплекс базових рухів" та "танцювальна зв'язка”; “Той-Тач”, "Пайп” та "Навколо віту”; “Основна стійка”, “Стег”, “Ліберті”, "Прапорецьь” та "Скорпіон”; “перекид вперед”, “перекид назад”, “стійка на руках”, “переворот боком”, “Рандат”, “гімнастичний міст”, "переворот вперед на дві ноги”, “переворот вперед на одну ногу”, “переворот назад на одну ногу” “" “темповий” переворот вперед”.

За результатами аналізу технічної підготовленості черлідирів-флаєрів 9-10 років на початку впровадження експериментальної методики, необхідно зазначити наступне, що контрольна та експериментальна групи на внутрішньогруповому рівні не мали достовірних

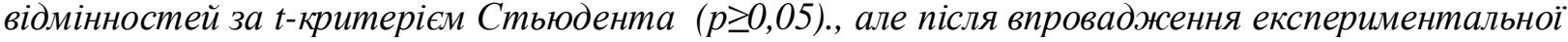
методики рівень технічної підготовленості, як у контрольній, так $i$ у експериментальній групах, став вищий. У комплексі тестів “базових рухів черлідингу” у контрольній групі середні показники лишилися на рівні вище середнього (від 4,04 до 4,21), а у експериментальній групі рівень оцінок перейшов від вище середнього на високий (від 4,58 до 4,65); комплекс тестів "Черстрибків" експериментальної групи підвищився до високого рівня ("Той-Тач” - 4,5; "Пайп” 4.62; "Навколо світу” - 4,54); приріст показників у комплексі тестів “складність положень флаєра” в експериментальній групі більший, а ніж в контрольній у всіх тестах окрім контрольного тесту - положення флаєра "Основна стійка"; середньо арифметичний показник виконання акробатичних елементів у контрольній групі відповідає рівню вище середнього - 6,65 балів, а у експериментальній групі - високому рівню 8,52 бали.

Ключові слова: черлідинг, черлідири-база, технічна підготовка, технічна підготовленість, спеціальна технічна підготовка, етап попередньої базової підготовки.

У складнокоординаційних видах спорту, таких як черлідинг, спортивний результат досягається завдяки суб'єктивній оцінці суддів за бездоганну технічну майстерність, виконання змагальних вправ, тому технічна підготовка у навчально-тренувальному процесі займає провідне місце та домінує над іншими $[1,2,16]$. Технічна підготовка забезпечує фрормування таких навичок виконання змагальних дій, які дозволили б черлідирам 3 найбільшою ефективністю використовувати свої можливості у змаганнях, а також неухильно вдосконалювали б технічну майстерність у процесі багаторічних занять спортом [6].

3 метою узагальнення питань вдосконалення технічної підготовки черлідирів-фрлаєрів на етапі попередньої базової підготовки використовувався теоретичний аналіз, узагальнення науково-методичної літератури та Інтернет- 
ресурсів. Аналіз програмно-нормативних матеріалів надав можливість визначити особливості технічної підготовки черлідирів-флаєрів [9, 10], а педагогічне тестування дозволило визначити рівень технічної підготовленості за контрольними тестами: базові рухи черлідингу, Чер-стрибки, складність положень фрлаєра та акробатичні елементи.

Дослідження виконане згідно Зведеного плану НДР у сфері фрізичної культури і спорту на 2016-2020 рр. за темою: “Історичні, організаційно-правові та теоретико-методичні основи підготовки спортсменів в неолімпійському спорті" державний реєстраційний номер 0116 U003008.

Мета дослідження - проаналізувати результати етапного контролю оцінки рівня технічної підготовленості черлідирів-фрлаєрів після впровадження експериментальної методики.

Методи дослідження: аналіз науково-методичної літератури, аналіз документальних матеріалів, педагогічне тестування.

Учасниками дослідження були 100 спортсменів-черлідирів віком 9-10 років СK "Angels" (м. Київ), Вища школа черлідингу (м. Одеса) та Всеукраїнський СК “Тріумф” (м. Дніпро), з них 50 черлідирів-флаєрів та 50 черлідирів-бази. Від усіх учасників було отримано інформовану згоду на участь в цьому дослідженні.

Організація дослідження: Дослідження проводилося на початку третього року тренувань етапу попередньої базової підготовки.

Експериментальна методика охоплювала три рівня технічної підготовки для яких було окремо визначено мету та завдання підготовки, власні засоби та методи спортивного тренування та планувалися відповідно до структури двохциклової річної підготовки з урахування поставлених завдань мезоциклу.

На першому рівні технічної підготовки спортсменів-черлідирів наша методика складала з фронтальної підготовки фрлаєрів та бази. Основними компонентами технічної підготовки було визначено: положення рук, Черстрибки, акробатичні елементи на онові яких й складається наша методика.

Метою першого рівня підготовки є повторення і вдосконалення навичок технічної підготовки, сорормованих на етапі початкової підготовки з черлідингу.

На другому рівні методика окремо складалась з підготовки черлідирівфрлаєрів та черлідирів-бази, що дозволило більш індивідуально підійти до питання щодо підвищення рівня технічної підготовки кожного з членів команди.

Метою другого рівня $є$ формування навичок технічної підготовки, вивчення та закріплення елементів вищого рівня складності, характерних для етапу початкової базової підготовки.

Змагальна діяльність - це незамінна школа вдосконалення здібностей спортсменів, їх умінь та навичок у структурі змагальної композиції. Тому третій рівень методики складався безпосередньо з підготовки та виступу команди на змаганнях, які входили до річного плану загань.

Метою третього рівня є підвищення рівня змагальної композиції 3 черлідингу на етапі попередньої базової підготовки.

Статистичний аналіз: обробка результатів дослідження здійснювалася на загальногруповому рівні використовуючи програмне забезпечення "Statistica 
6.0" та програмного додатку MS Excel (2010).

Результати дослідження та їх обговорення. В основу експериментальної методики вдосконалення технічної підготовки черлідирів на етапі попередньої базової підготовки першого року тренувань було покладено теоретичні положення: теорії та методики спортивного тренування В. Н. Платонова [11]; системи підготовки спортсменів в техніко-естетичних видах спорту Н.Г. Демідова [3], В.В. Тодорова [14]; основних закономірностей процесу навчання та вдосконалення техніки фрізичних вправ у складнокординаційних видах спорту Н. Г. Долбишева, В.В.Кидонь [4, 5], А. А. Топол [15] та ін.; особливостей підготовки та змагальної діяльності у черлідингу А. А. Боляк [2], А. Н. Бекетова [1], І. А. Зинченко, Л. С. Луценко, І. А. Бодренкова [7, 8], Е. А. Самохина, Н. В. Седих [12], Р. Чеппел [16] та ін. Також при розробці експериментальної методики ураховувалися результати попередніх досліджень щодо місця та значення технічної підготовки в навчальнотренувальному процесі юних спортсменів-черлідирів на етапі попередньої базової підготовки [9], вихідного рівня технічної та фрізичної підготовленості спортсменок-черлідирів, які виконують в процесі змагальної композиції різні фрункції (“базу” (перший рівень пірамід) та "фрлаєри” (другий та третій рівень пірамід) [6].

Експериментальна методика охоплює три рівня технічної підготовки для яких було окремо визначено мету та завдання підготовки, власні засоби та методи спортивного тренування та планувалися відповідно до структури двохциклової річної підготовки з урахування поставлених завдань мезоциклу.

Під час проведення попереднього педагогічного дослідження рівень технічної підготовленості черлідирів визначався за підібраними нами контрольними тестами, які були об'єднані в чотири групи комплексних критеріїв: базові рухи черлідингу, чер-стрибки, складність положень фрлаєра, технічне виконання акробатичних елементів.

За результатами аналізу технічної підготовленості, щодо базових рухів черлідингу черлідирів-фрлаєрів 9-10 років на початку впровадження експериментальної методики, що представлені в таблиці 1, необхідно зазначити наступне:

- контрольна та експериментальна групи на внутрішньогруповому рівні не мали достовірних відмінностей за t-критерієм Стьюдента $(p \geq 0,05)$. Також слід зазначити, що, за результатами попереднього тестування, рівень технічної підготовленості у контрольних тестах, знаходився на рівні вище середнього (контрольна група від 3,67 балів до 3,79 балів, експериментальна група від 4,19 балів до 4,27 балів);

- в двох групах коефріцієнт варіації складав від 13,53\% до 20,55\%, що свідчить про середні та сильні розбіжність показників та їх неоднорідність. 
Показники технічної підготовленості черлідирів-фласрів контрольної та експериментальної груп до та після педагогічного експерименту (на внутрішньогруповому рівні)

\begin{tabular}{|c|c|c|c|c|c|c|c|c|c|}
\hline \multirow{2}{*}{$\begin{array}{l}\text { № } \\
\mathrm{n} / \\
\mathrm{n}\end{array}$} & \multirow{2}{*}{$\begin{array}{l}\text { Контрольні } \\
\text { тести }\end{array}$} & \multirow{2}{*}{$\begin{array}{l}\text { Крупа } \\
\text { стат-ні } \\
\text { показники }\end{array}$} & \multicolumn{2}{|c|}{$\begin{array}{l}\text { Контрольна } \\
\text { група }(\mathrm{n}=12)\end{array}$} & \multirow{2}{*}{$\begin{array}{l}\mathrm{p} \\
\mathrm{t}_{\text {розр. }}\end{array}$} & \multicolumn{3}{|c|}{$\begin{array}{l}\text { Експериментальна } \\
\text { група }(\mathrm{n}=12)\end{array}$} & \multirow{2}{*}{$\begin{array}{l}\mathrm{p} \\
\mathrm{t}_{\text {розр. }}\end{array}$} \\
\hline & & & до & після & & \multicolumn{2}{|c|}{ До } & після & \\
\hline \multicolumn{10}{|c|}{ Базові рухи черлідингу } \\
\hline \multirow{5}{*}{1} & \multirow{5}{*}{$\begin{array}{l}\text { Комплекс } \\
\text { базових рухів }\end{array}$} & $\bar{x}$ & 3,79 & 4,21 & \multirow{3}{*}{\multicolumn{2}{|c|}{$\begin{array}{l}\geq 0,05 \\
2,194\end{array}$}} & 4,19 & 4,58 & \multirow{3}{*}{$\begin{array}{l}\geq 0,05 \\
2,585\end{array}$} \\
\hline & & $\mathrm{S}$ & 0,78 & 0,51 & & & 0,57 & 0,50 & \\
\hline & & $\mathrm{V}$ & 20,55 & 12,09 & & & 13,53 & 11,01 & \\
\hline & & $\mathrm{p}, \mathrm{t}_{\text {розр }}$ (до) & \multicolumn{7}{|c|}{$\geq 0,05 ; 2,065$} \\
\hline & & $\begin{array}{ll}\mathrm{p}, & \mathrm{t}_{\text {розр }} \\
\text { (після) } & \\
\end{array}$ & \multicolumn{7}{|c|}{$\geq 0,05 ; 2,571$} \\
\hline \multirow{5}{*}{2} & \multirow{5}{*}{$\begin{array}{l}\text { Танцювальна } \\
\text { зв’язка }\end{array}$} & $x$ & 3,67 & 4,04 & \multirow{3}{*}{\multicolumn{2}{|c|}{$\begin{array}{l}\geq 0,05 \\
2,065\end{array}$}} & 4,27 & 4,65 & \multirow{3}{*}{$\begin{array}{l}\geq 0,05 ; \\
2,532\end{array}$} \\
\hline & & $\mathrm{S}$ & 0,70 & 0,55 & & & 0,60 & 0,49 & \\
\hline & & $\mathrm{V}$ & 19,14 & 13,61 & & & 14,14 & 10,43 & \\
\hline & & $\mathrm{p}, \mathrm{t}_{\text {розр }}($ до $)$ & \multicolumn{7}{|c|}{$\geq 0,01 ; 3,242$} \\
\hline & & $\begin{array}{ll}\mathrm{p}, & \mathrm{t}_{\text {розр }} \\
\text { (після) } & \end{array}$ & \multicolumn{7}{|c|}{$\geq 0,001 ; 4,160$} \\
\hline
\end{tabular}

Аналіз результатів табличних даних 1, отриманих наприкінці річного циклу, дозволив встановити такі критерії ефрективності впровадженої нами методики:

- рівень технічної підготовленості, як у контрольній, так і у експериментальній групах, став вищий. Так, у контрольній групі середні показники лишилися на рівні вище середнього (від 4,04 до 4,21), а у експериментальній групі - рівень оцінок перейшов від вище середнього на високий (від 4,58 до 4,65);

- на внутрішньогруповій вибірці відмінності від результатів на початку річного циклу спостерігалися в однорідності показників в контрольній групі у тестах “комплекс базових рухів" ( $V=12,09 \%)$ та "танцювальна зв'язка" ( $V=$ $13,61 \%)$, в експериментальній групі - у тестах "комплекс базових рухів" ( $V=$ $11,01 \%)$ та "танцювальна зв'язка” ( $V=10,43 \%)$. Так, отримані коефріцієнти варіації свідчать про сукупність показників 3 технічної підготовленості черлідирів-фрлаєрів, щодо базових рухів черлідингу.

- приріст показників у відсотках за контрольними тестами в контрольній групі склав від 7,4\% до 8,4\%, в експериментальній - від 7,6\% до 7,8\% (рис. 1), отже спостерігається не значна відмінність приросту показників у контрольній та експериментальній групі, але рівень виконання тесту “танцювальна зв'язка" у експериментальній групі підвищився з вище середнього до високого.

достовірний приріст за t-критерієм Стьюдента при $p \geq 0,05$ спостерігається в контрольній та експериментальній групі між показниками на початку та наприкінці річного циклу у контрольних тестах "комплекс базових рухів" та “танцювальна зв'язка”. У даних контрольного тесту “танцювальна зв'язка” 
встановлено достовірну відмінність при $p \leq 0,001$ між контрольною та експериментальною групами наприкінці педагогічного експерименту. Представлені результати в таблиці 1 свідчать про достовірність розбіжностей між контрольною та експериментальною групами після педагогічного експерименту у контрольних тестах - “комплекс базових рухів" та “танцювальна зв'язка”.

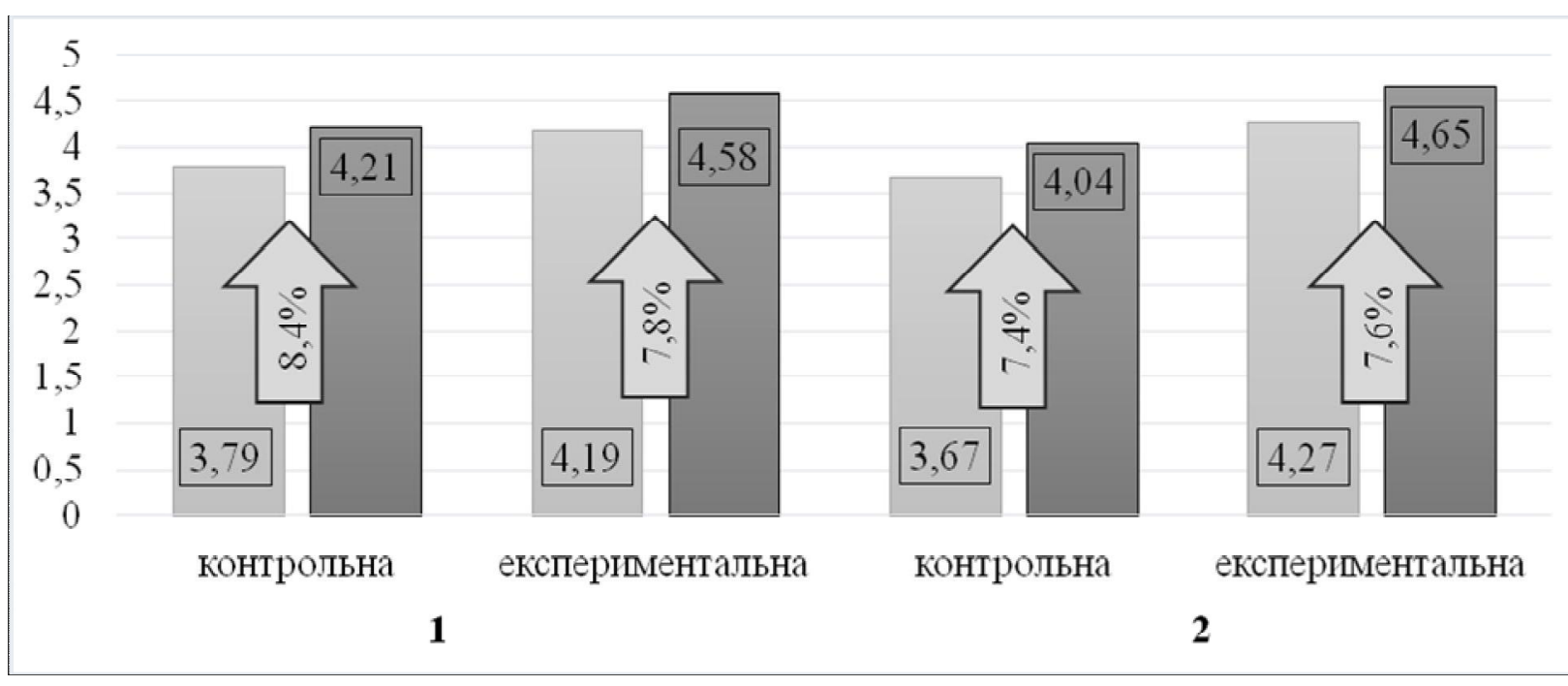

Рис. 1. Приріст показників з технічної підготовленості контрольної та експериментальної груп черлідирів-флаєрів наприкінці річного ичиклу підготовки:

$\square-$ до експерименту, $\square-$ після експерименту:
1 - Комплекс базових рухів, 2 - танцювальна зв'язка

Також для визначення ефективності розробленої нами методики було проведено аналіз результатів технічної підготовки черлідирів-фрлаєрів, щодо Чер-стрибків на початку та наприкінці констатуючого експерименту.

Попередньо отримані результати (табл. 2) свідчать про те, що рівень виконання Чер-стрибків у контрольній та експериментальній групах $\epsilon$ однорідний.

Відповідно до отриманих даних після експерименту:

- експериментальна група має достовірний приріст результатів у таких тестах, як: "Той-Тач", “Пайп”, де $p \geq 0,01$ та "Навколо світу”, де $p \geq 0,001$. Також слід зазначити, що, за результатами експертів, рівень технічної підготовленості, щодо Чер-стрибків експериментальної групи у всіх трьох контрольних тестах підвищився до високого рівня (“Той-Тач" - 4,5; "Пайп" 4.62; “Навколо світу" - 4,54);

- в двох групах коефіцієнт варіації складав від 10,75\% до 17,35\%, що свідчить про середні розбіжність показників та їх неоднорідність;

- приріст показників у відсотках за контрольними тестами, щодо визначення рівня Чер-стрибків у контрольній групі склав від 2,4\% до 9,2\%, а в експериментальній від 11,6\% до 13,8\%. Більш детальний приріст 
представлений на рисунку 2. Найбільший приріст результатів спостерігався в експериментальній групі у контрольних тестах Чер-стрибків "Той-Тач" та "Пайп" на $8,2 \%$ та 9,2\% (відповідно), що свідчить про значну технічну майстерність виконання даних вправ черлідингу.

- найбільший приріст результатів у балах спостерігався в експериментальній групі у контрольному тесті "Навколо світу" 0,69 бали), що свідчить про значну технічну майстерність виконання даного Чер-стрибка черлідирами-фллаєрами. Найменший приріст результатів визначився в контрольній групі у тесті “Той-Тач” 0,25 бали.

Таблиця 2

Показники технічної підготовленості черлідирів-фласрів контрольної та експериментальної груп до та після педагогічного експерименту (на внутрішньогруповому рівні

\begin{tabular}{|c|c|c|c|c|c|c|c|c|}
\hline \multirow{2}{*}{$\begin{array}{l}\text { № } \\
\text { n/n }\end{array}$} & \multirow{2}{*}{$\begin{array}{l}\text { Контрольні } \\
\text { тести }\end{array}$} & \multirow{2}{*}{ Група } & \multicolumn{2}{|c|}{$\begin{array}{l}\text { Контрольна } \\
\text { група }(\mathrm{n}=12)\end{array}$} & \multirow{2}{*}{$\begin{array}{l}\mathrm{p} \\
\mathrm{t}_{\text {розр. }}\end{array}$} & \multicolumn{2}{|c|}{$\begin{array}{l}\text { Експериментальна } \\
\text { група }(\mathrm{n}=12)\end{array}$} & \multirow{2}{*}{$\begin{array}{l}\mathrm{p}, \\
\mathrm{t}_{\text {розр. }}\end{array}$} \\
\hline & & & до & після & & До & після & \\
\hline \multicolumn{9}{|c|}{ Чер-стрибки } \\
\hline \multirow{5}{*}{3} & \multirow{5}{*}{ Той-Тач } & $x$ & 3,96 & 4,21 & \multirow{3}{*}{$\begin{array}{l}\leq 0,05 \\
1,350\end{array}$} & 3,92 & 4,50 & \multirow{3}{*}{$\begin{array}{l}\geq 0,01 \\
2,981\end{array}$} \\
\hline & & $S$ & 0,69 & 0,59 & & 0,84 & 0,51 & \\
\hline & & $\mathrm{V}$ & 17,44 & 13,98 & & 21,54 & 11,33 & \\
\hline & & $\mathrm{p}, \mathrm{t}_{\text {розр }}$ (до) & \multicolumn{6}{|c|}{$\leq 0,05 ; 0,162$} \\
\hline & & $\begin{array}{ll}\mathrm{p}, & \mathrm{t}_{\text {розр }} \\
\text { (після) } & \\
\end{array}$ & \multicolumn{6}{|c|}{$\leq 0,05 ; 1,867$} \\
\hline \multirow{5}{*}{4} & \multirow{5}{*}{ Пайп } & $x$ & 3,92 & 4,33 & \multirow{3}{*}{$\begin{array}{l}\leq 0,05 \\
2,034\end{array}$} & 4,08 & 4,62 & \multirow{3}{*}{$\begin{array}{l}\geq 0,01 \\
3,070\end{array}$} \\
\hline & & $\mathrm{S}$ & 0,78 & 0,64 & & 0,74 & 0,50 & \\
\hline & & $\mathrm{V}$ & 19,80 & 14,70 & & 18,25 & 10,75 & \\
\hline & & $\mathrm{p}, \mathrm{t}_{\text {розр }}$ (до) & \multicolumn{6}{|c|}{$\leq 0,05 ; 0,744$} \\
\hline & & $\begin{array}{ll}\mathrm{p}, & \mathrm{t}_{\text {розр }} \\
\text { (після) } & \end{array}$ & \multicolumn{6}{|c|}{$\leq 0,05 ; 1,737$} \\
\hline \multirow{5}{*}{5} & \multirow{5}{*}{ Навколо світу } & $x$ & 3,79 & 4,25 & \multirow{3}{*}{$\begin{array}{l}\leq 0,05 \\
2,019\end{array}$} & 3,85 & 4,54 & \multirow{3}{*}{$\begin{array}{l}\geq 0,001 \\
3,96\end{array}$} \\
\hline & & $S$ & 0,83 & 0,74 & & 0,73 & 0,51 & \\
\hline & & $\mathrm{V}$ & 21,97 & 17,35 & & 19,02 & 11,20 & \\
\hline & & $\mathrm{p}, \mathrm{t}_{\text {розр }}$ (до) & \multicolumn{6}{|c|}{$\leq 0,05 ; 0,245$} \\
\hline & & $\begin{array}{ll}\mathrm{p}, & \mathrm{t}_{\text {розр }} \\
\text { (після) } & \end{array}$ & \multicolumn{6}{|c|}{$\leq 0,05 ; 1,598$} \\
\hline
\end{tabular}

Рівень складності положень черлідира-фрлаєра був наступним критерієм визначення рівня розвитку технічної підготовки після впровадження експериментальної методики. Слід зазначити, що контрольна та експериментальна група на внутрішньогруповому рівні не мали суттєвих відмінностей за t-критерієм Стьюдента ( $p \geq 0,05)$. А отримані дані вказують на достовірну розбіжність між контрольною та експериментальною групами наприкінці педагогічного експерименту у більшості тестах: "Стег", "Прапорець" та “Скорпіон”, де $p \geq 0,001$ (табл. 3). 


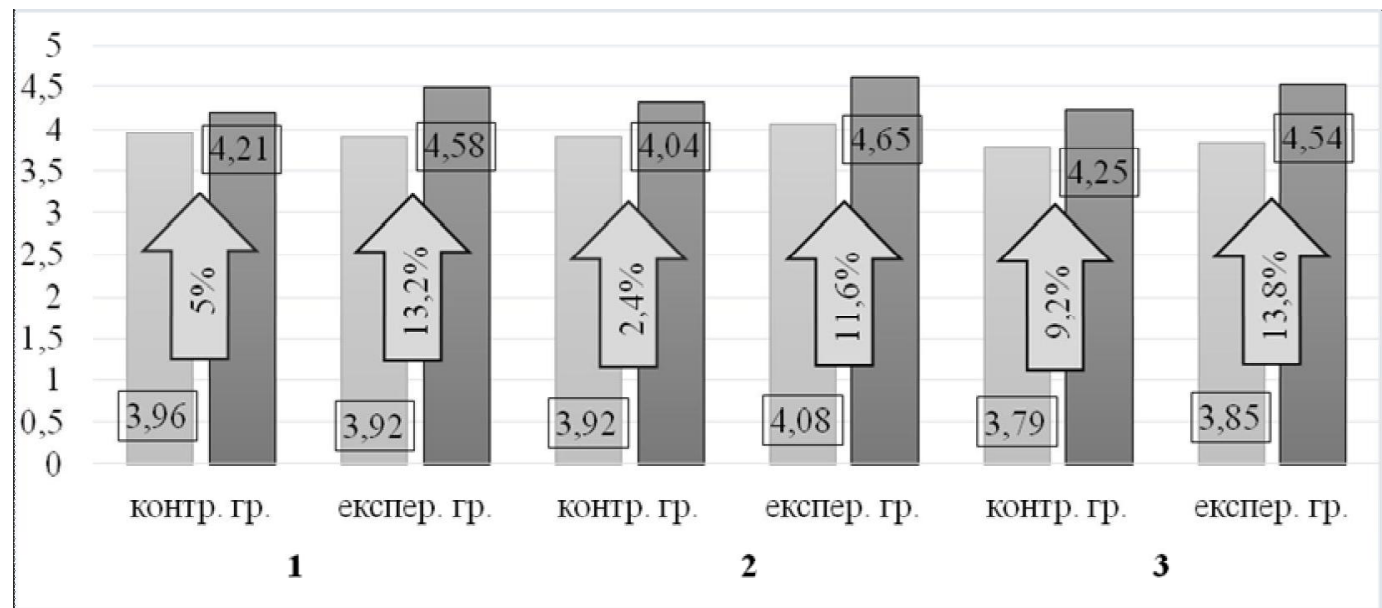

Рис. 2. Приріст показників з технічної підготовленості контрольної та експериментальної груп черлідирів-флаєрів наприкінці річного циклу підготовки:

- до експерименту, $\square-$ після експерименту:

1 - "Той-Тач"; 2 - "Пайп”; 3 - "Навколо світу"

Аналізуючи отримані дані можна зробити висновок, що рівень складності положень фрлаєра, як в контрольні так і в експериментальній групі став вищих. Але в контрольні групі достовірний приріст результатів, де $p \geq 0,01$, спостерігається лише в одному положенні "Ліберті", та одному положенні "Основна стійка", де $p \geq 0,05$ ми маємо звернути увагу на те, що в експериментальній групі достовірний приріст результатів $є$ у всіх тестах: "Основна стійка", $p \geq 0,05$; "Ліберті", $p \geq 0,001$; "Стег”, $p \geq 0,001$; "Прапорець", $p \geq 0,001$; “Скорпіон", $p \geq 0,001$.

Таблиця 3

\section{Показники технічної підготовленості черлідирів-фласрів контрольної та експериментальної груп до та після педагогічного експерименту (на внутрішньо груповому рівні)}

\begin{tabular}{|c|c|c|c|c|c|c|c|c|c|}
\hline \multirow{2}{*}{$\begin{array}{l}\text { № } \\
\mathrm{n} / \mathrm{n}\end{array}$} & \multirow{2}{*}{$\begin{array}{l}\text { Контрольні } \\
\text { тести }\end{array}$} & \multirow{2}{*}{$\begin{array}{l}\text { Група } \\
\text { стат-ні } \\
\text { показники }\end{array}$} & \multicolumn{2}{|c|}{$\begin{array}{l}\text { Контрольна } \\
\text { група }(\mathrm{n}=12)\end{array}$} & \multirow{2}{*}{$\begin{array}{l}\mathrm{p} \\
\mathrm{t}_{\text {pозр. }}\end{array}$} & \multicolumn{3}{|c|}{$\begin{array}{l}\text { Експериментальна } \\
\text { група }(\mathrm{n}=12)\end{array}$} & \multirow{2}{*}{$\begin{array}{l}\mathrm{p} \\
\mathrm{t}_{\text {розр. }}\end{array}$} \\
\hline & & & до & після & & \multicolumn{2}{|c|}{ до } & після & \\
\hline \multicolumn{10}{|c|}{ Рівні складності положень черлідира-флаєра } \\
\hline \multirow{5}{*}{1} & \multirow{5}{*}{$\begin{array}{l}\text { Основна } \\
\text { стійка }\end{array}$} & $\bar{x}$ & 8,50 & 9,21 & \multirow{3}{*}{$\begin{array}{l}\geq 0,05 \\
; \\
2,775\end{array}$} & \multicolumn{2}{|c|}{8,85} & 9,42 & \multirow{3}{*}{$\begin{array}{l}\geq 0,05 \\
2,698\end{array}$} \\
\hline & & $\mathrm{S}$ & 1,10 & 0,59 & & \multirow{2}{*}{\multicolumn{2}{|c|}{\begin{tabular}{|l|}
0,78 \\
8,87
\end{tabular}}} & 0,76 & \\
\hline & & V & 12,98 & 6,39 & & & & 8,04 & \\
\hline & & $\mathrm{p}, \mathrm{t}_{\text {розр }}($ до) & \multicolumn{7}{|c|}{$\leq 0,05 ; 1,269$} \\
\hline & & $\begin{array}{ll}\mathrm{p}, & \mathrm{t}_{\text {розр }} \\
\text { (після) } & \end{array}$ & \multicolumn{7}{|c|}{$\leq 0,05 ; 1,124$} \\
\hline \multirow[t]{3}{*}{2} & \multirow[t]{3}{*}{ Ліберті } & $x$ & 7,25 & 8,42 & \multirow{3}{*}{\multicolumn{2}{|c|}{$\begin{array}{l}\geq 0,01 \\
3,179\end{array}$}} & 7,04 & 8,77 & \multirow{3}{*}{$\begin{array}{l}\geq 0,001 \\
4,662\end{array}$} \\
\hline & & $\mathrm{S}$ & 1,45 & 1,06 & & & 1,54 & 1,11 & \\
\hline & & $\mathrm{V}$ & 20,03 & 12,59 & & & 21,82 & 12,62 & \\
\hline
\end{tabular}




\begin{tabular}{|c|c|c|c|c|c|c|c|c|}
\hline \multirow{4}{*}{$\begin{array}{l}\text { № } \\
\text { n/n }\end{array}$} & \multirow{4}{*}{$\begin{array}{l}\text { Контрольні } \\
\text { тести }\end{array}$} & Група & \multicolumn{2}{|c|}{$\begin{array}{l}\text { Контрольна } \\
\text { група }(\mathrm{n}=12)\end{array}$} & \multirow{2}{*}{$\begin{array}{l}\mathrm{p} \\
\mathrm{t}_{\text {pозр }}\end{array}$} & \multicolumn{2}{|c|}{$\begin{array}{l}\text { Експериментальна } \\
\text { група }(\mathrm{n}=12)\end{array}$} & \multirow{2}{*}{$\begin{array}{l}\mathrm{p} \\
\mathrm{t} \text { розр. }\end{array}$} \\
\hline & & $\begin{array}{l}\text { стат-ні } \\
\text { показники }\end{array}$ & до & після & & до & після & \\
\hline & & $\mathrm{p}, \mathrm{t}_{\text {розр }}$ (до) & \multicolumn{6}{|c|}{$\leq 0,05 ; 0,501$} \\
\hline & & $\begin{array}{ll}\mathrm{p}, & \mathrm{t}_{\text {розр }} \\
\text { (після) } & \end{array}$ & \multicolumn{6}{|c|}{$\leq 0,05 ; 1,151$} \\
\hline \multirow{5}{*}{3} & \multirow{5}{*}{ Стег } & $x$ & 5,79 & 6,21 & \multirow{3}{*}{$\begin{array}{l}\leq 0,05 \\
0,989\end{array}$} & 6,12 & 8,04 & \multirow{3}{*}{$\begin{array}{l}\geq 0,001 \\
4,771\end{array}$} \\
\hline & & $\mathrm{S}$ & 1,61 & 1,28 & & 1,58 & 1,31 & \\
\hline & & $\mathrm{V}$ & 27,88 & 20,69 & & 25,89 & 16,31 & \\
\hline & & $\mathrm{p}, \mathrm{t}_{\text {розр }}$ (до) & \multicolumn{6}{|c|}{$\leq 0,05 ; 0,715$} \\
\hline & & $\begin{array}{l}\mathrm{p}, \\
\text { (після) }\end{array}$ & \multicolumn{6}{|c|}{$\geq 0,001 ; 4,984$} \\
\hline \multirow{5}{*}{4} & \multirow{5}{*}{ Прапорець } & $x$ & 5,29 & 5,88 & \multirow{3}{*}{$\begin{array}{l}\leq 0,05 \\
1,598\end{array}$} & 5,62 & 8,08 & \multirow{3}{*}{$\begin{array}{l}\geq 0,001 \\
5,777\end{array}$} \\
\hline & & $\mathrm{S}$ & 1,37 & 1,15 & & 1,44 & 1,62 & \\
\hline & & $\mathrm{V}$ & 25,83 & 19,64 & & 25,72 & 20,09 & \\
\hline & & $\mathrm{p}, \mathrm{t}_{\text {розр }}$ (до) & \multicolumn{6}{|c|}{$\leq 0,05 ; 0,814$} \\
\hline & & $\begin{array}{ll}\mathrm{p}, & \mathrm{t}_{\text {розр }} \\
\text { (після) } & \end{array}$ & \multicolumn{6}{|c|}{$\geq 0,001 ; 5,561$} \\
\hline \multirow{5}{*}{5} & \multirow{5}{*}{ Скорпіон } & $\bar{x}$ & 3,38 & 4,58 & \multirow{3}{*}{$\begin{array}{l}\leq 0,05 \\
2,010\end{array}$} & 4,08 & 7,12 & \multirow{3}{*}{$\begin{array}{l}\geq 0,001 \\
4,954\end{array}$} \\
\hline & & $\mathrm{S}$ & 2,60 & 1,38 & & 2,62 & 1,70 & \\
\hline & & $\mathrm{V}$ & 77,07 & 30,12 & & 64,31 & 23,96 & \\
\hline & & $\mathrm{p}, \mathrm{t}_{\text {розр }}$ (до) & \multicolumn{6}{|c|}{$\leq 0,05 ; 0,950$} \\
\hline & & $\begin{array}{ll}\mathrm{p}, & \mathrm{t}_{\text {розр }} \\
\text { (після) } & \end{array}$ & \multicolumn{6}{|c|}{$\geq 0,001 ; 5,791$} \\
\hline
\end{tabular}

На внутрішньогруповій вибірці відмінності від результатів на початку річного циклу спостерігається в збільшені однорідності показників в контрольні та експериментальній групі під час тесту “Скорпіон” V=30,12\% та V=23,96\%, замість $\mathrm{V}=77,07 \%$ та $\mathrm{V}=64,31 \%$ відповідно.

Найбільший приріст показників у відсотках за контрольними тестами $є$ в експериментальній групі у тестах 4-го та 5-го рівня складності, “Прапорець” 24,6\% та "Скорпіон" - 30,4\% (рис. 3).

Необхідно зазначити, що в одному контрольному тесті Чер-стрибок "Пайп" у контрольній групі приріст склав у більше, ніж у експериментальній. Це можна пояснити тим, що вихідний рівень показника у контрольній групі був нижчий на 0,29 балів;

Розглядаючи дані результати більш детально, можна зробити висновок про те, що приріст показників у відсотках в експериментальній групі більший, а ніж в контрольній у всіх тестах окрім контрольного тесту - положення фрлаера "Основна стійка", у якому приріст результатів контрольної групи становить 7,1\%, а експериментальної - 5,7\%.

Для дослідження рівня акробатичної підготовленості черлідирів-фрлаєрів після педагогічного експерименту, було обрано 10 тестів (табл. 4). Слід зазначити, що до експерименту між контрольною та експериментальною групами у всіх тестах не визначилось достовірних відмінностей за t-критерієм Стьюдента ( $p \geq 0,05)$. 


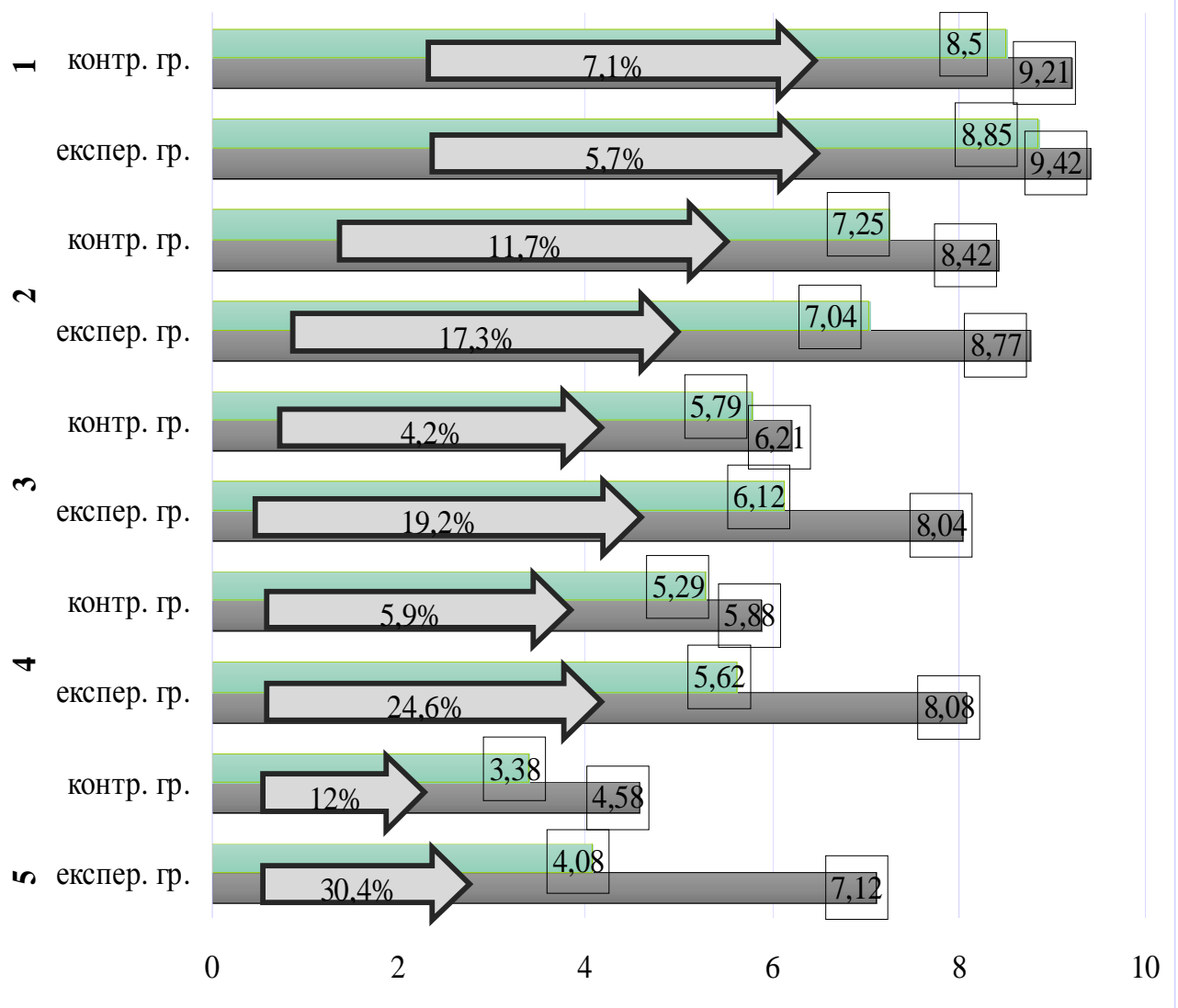

Рис. 3. Приріст показників з технічної підготовленості контрольної та експериментальної груп черлідирів-флаєрів наприкінці річного цииклу підготовки:

$\square$ - до експерименту, $\square$ - після експерименту:

1 - “Основна стійка"; 2 - “Ліберті”; 3 - “Стег”; 4 - "Прапорець”; 2 - “Скорпіон”

Рівень виконання тестів з акробатичної підготовки до експерименту варіювався з нижче середнього до високого, але після впровадженої нами методики результати змінились:

- контрольний тест “темповий переворот вперед" в експериментальній групі став на рівні вище середнього (7,5 балів), в контрольній групі показники даного тесту збільшилися, але залишилися на рівні нижче середнього (3,88 балів);

- контрольні тести “переворот назад на одну ногу", “переворот вперед на одну ногу", "переворот вперед на дві ноги", "Рандат" та "стійка на руках" в експериментальній групі були виконані краще та з середнього рівня перейшли на рівень вище середнього (7,92 балів, 8,31 бали, 8,15 балів, 8,08 балів та 8,42 бали відповідно), в контрольній групі показники залишилися на середньому рівні (5,25 балів, 5,58 балів, 6,13 балів, 5,75 балів та 6,04 бали відповідно);

- у контрольному тесті “Міст” в експериментальній групі показники зросли 
від вище середнього до високо рівня (8,65 балів), а в контрольній групі показники залишилися на рівні вище середнього (7 балів);

- рівень виконання контрольних тестів “переворот в сторону ("колесо")" та “перекид назад” в обох групах однаково покращився та перейшов на високий рівень, в експериментальній групі - 9,15 балів та 9,35 бали відповідно, в контрольній - 8,5 балів та 8,92 бали відповідно;

- контрольний тест “перекид вперед" в обох групах залишився на високому рівні, в експериментальній групі середньоарифметична оцінка - 9,62 бали, в контрольній - 9,42 бали. Це пов'язано з тим, що цей акробатичний елемент за рівнем складності є найлегшим.

Табличя 4

Показники технічної підготовленості черлідирів-фласрів контрольної та експериментальної груп до та після педагогічного експерименту (на внутрішньогруповому рівні)

\begin{tabular}{|c|c|c|c|c|c|c|c|c|}
\hline \multirow{2}{*}{$\begin{array}{l}\text { № } \\
\text { n/n }\end{array}$} & \multirow{2}{*}{$\begin{array}{l}\text { Контрольні } \\
\text { тести }\end{array}$} & \multirow{2}{*}{ Група } & \multicolumn{2}{|c|}{$\begin{array}{l}\text { Контрольна } \\
\text { група }(\mathrm{n}=12)\end{array}$} & \multirow{2}{*}{$\mathrm{p}, \mathrm{t}_{\text {розр. }}$} & \multicolumn{2}{|c|}{$\begin{array}{l}\text { Експериментальн } \\
\text { а група }(\mathrm{n}=12)\end{array}$} & \multirow{2}{*}{$\begin{array}{l}\mathrm{p} \\
\mathrm{t}_{\text {розр. }}\end{array}$} \\
\hline & & & до & після & & До & після & \\
\hline 1 & 2 & 3 & 4 & 5 & 6 & 7 & 8 & 9 \\
\hline \multicolumn{9}{|c|}{ Акробатичні елементи } \\
\hline \multirow[t]{5}{*}{1} & $\begin{array}{l}\text { Перекид } \\
\text { вперед }\end{array}$ & $\bar{x}$ & 9,25 & 9,42 & $\begin{array}{l}\leq 0,05 \\
0,736\end{array}$ & 9,08 & 9,62 & $\begin{array}{l}\geq 0,01 \\
3,070\end{array}$ \\
\hline & & $\mathrm{S}$ & 0,85 & 0,72 & & 0,74 & 0,50 & \\
\hline & & $\mathrm{V}$ & 9,16 & 7,62 & & 8,20 & 5,16 & \\
\hline & & $\mathrm{p}, \mathrm{t}_{\text {розр }}($ до) & \multicolumn{6}{|c|}{$\leq 0,05 ; 0,765$} \\
\hline & & $\begin{array}{l}\mathrm{p}, \\
\text { (після) }\end{array}$ & \multicolumn{6}{|c|}{$\leq 0,05 ; 1,130$} \\
\hline \multirow[t]{5}{*}{2} & \multirow[t]{5}{*}{ Перекид назад } & $\bar{x}$ & 8,46 & 8,92 & $\begin{array}{l}\leq 0,05 \\
1,558\end{array}$ & 8,46 & 9,15 & $\begin{array}{l}\geq 0,05 \\
2,282\end{array}$ \\
\hline & & $\mathrm{S}$ & 1,25 & 0,72 & & 1,24 & 0,92 & \\
\hline & & $\mathrm{V}$ & 14,78 & 8,04 & & 14,66 & 10,10 & \\
\hline & & $\mathrm{p}, \mathrm{t}_{\text {розр }}$ (до) & \multicolumn{6}{|c|}{$\leq 0,05 ; 0,009$} \\
\hline & & $\begin{array}{l}\mathrm{p}, \\
\text { (після) }\end{array}$ & \multicolumn{6}{|c|}{$\leq 0,05 ; 1,017$} \\
\hline \multirow[t]{5}{*}{3} & $\begin{array}{l}\text { Стійка } \\
\text { руках }\end{array}$ & $\bar{x}$ & 5,04 & 6,04 & $\begin{array}{l}\geq 0,05 \\
2,221\end{array}$ & 5,42 & 8,42 & $\begin{array}{l}\geq 0,001 \\
; \\
7,205\end{array}$ \\
\hline & & $\mathrm{S}$ & 1,78 & 1,30 & & 1,53 & 1,47 & \\
\hline & & $\mathrm{V}$ & 35,33 & 21,54 & & 28,17 & 17,50 & \\
\hline & & $\mathrm{p}, \mathrm{t}_{\text {розр }}($ до) & \multicolumn{6}{|c|}{$\leq 0,05 ; 0,810$} \\
\hline & & $\begin{array}{ll}\mathrm{p}, & \mathrm{t}_{\text {розр }} \\
\text { (після) } & \end{array}$ & \multicolumn{6}{|c|}{$\geq 0,001 ; 6,065$} \\
\hline \multirow[t]{5}{*}{4} & $\begin{array}{l}\text { Переворот } \\
\text { боком }\end{array}$ & $\bar{x}$ & 7,71 & 8,50 & $\begin{array}{l}\geq 0,05 \\
2,382\end{array}$ & 7,65 & 9,35 & $\begin{array}{l}\geq 0,001 \\
; \\
5,023\end{array}$ \\
\hline & & $\mathrm{S}$ & 1,33 & 0,93 & & 1,29 & 1,13 & \\
\hline & & $\mathrm{V}$ & 17,31 & 10,97 & & 16,91 & 12,08 & \\
\hline & & $\mathrm{p}, \mathrm{t}_{\text {розр }}$ (до) & \multicolumn{6}{|c|}{$\leq 0,05 ; 0,146$} \\
\hline & & $t_{\text {pозр }}$ & $\geq 0,01 ;$ & 2,897 & & & & \\
\hline
\end{tabular}




\begin{tabular}{|c|c|c|c|c|c|c|c|c|}
\hline \multirow{2}{*}{$\begin{array}{l}\text { № } \\
\text { n/n }\end{array}$} & \multirow{2}{*}{$\begin{array}{l}\text { Контрольні } \\
\text { тести }\end{array}$} & \multirow{2}{*}{$\begin{array}{l}\text { Група } \\
\text { стат-ні } \\
\text { показники }\end{array}$} & \multicolumn{2}{|c|}{$\begin{array}{l}\text { Контрольна } \\
\text { група }(\mathrm{n}=12)\end{array}$} & \multirow{2}{*}{$\mathrm{p}, \mathrm{t}_{\text {розр. }}$} & \multicolumn{2}{|c|}{$\begin{array}{l}\text { Експериментальн } \\
\text { а група }(\mathrm{n}=12)\end{array}$} & \multirow{2}{*}{$\begin{array}{l}\mathrm{p} \\
\mathrm{t}_{\text {розр. }}\end{array}$} \\
\hline & & & до & після & & До & після & \\
\hline \multirow[t]{2}{*}{1} & 2 & 3 & 4 & 5 & 6 & 7 & 8 & 9 \\
\hline & & (після) & & & & & & \\
\hline \multirow[t]{5}{*}{5} & "Рандат" & - & 5,17 & 5,75 & $\begin{array}{l}\leq 0,05 \\
1,595\end{array}$ & 5,69 & 8,08 & $\begin{array}{l}\geq 0,001 \\
; \\
6,360\end{array}$ \\
\hline & & $S$ & 1,27 & 1,26 & & 1,41 & 1,29 & \\
\hline & & $\mathrm{V}$ & 24,66 & 21,91 & & 24,73 & 16,02 & \\
\hline & & $\mathrm{p}, \mathrm{t}_{\text {розр }}$ (до) & \multicolumn{6}{|c|}{$\leq 0,05 ; 1,386$} \\
\hline & & $\begin{array}{ll}\mathrm{p}, & \mathrm{t}_{\text {розр }} \\
\text { (після) } & \\
\end{array}$ & \multicolumn{6}{|c|}{$\geq 0,001 ; 6,441$} \\
\hline \multirow{5}{*}{6} & \multirow{5}{*}{$\begin{array}{l}\text { "гімнастичний } \\
\text { міст” }\end{array}$} & $x$ & 6,58 & 7,00 & \multirow{3}{*}{$\begin{array}{l}\leq 0,05 \\
1,387\end{array}$} & 6,73 & 8,65 & \multirow{3}{*}{$\begin{array}{l}\geq 0,001 \\
; \\
6,081\end{array}$} \\
\hline & & $\mathrm{S}$ & 1,14 & 0,93 & & 0,92 & 1,32 & \\
\hline & & $\mathrm{V}$ & 17,30 & 13,32 & & 13,65 & 15,31 & \\
\hline & & $\mathrm{p}, \mathrm{t}_{\text {розр }}$ (до) & \multicolumn{6}{|c|}{$\leq 0,05 ; 0,501$} \\
\hline & & $\begin{array}{ll}\mathrm{p}, & \mathrm{t}_{\text {розр }} \\
\text { (після) } & \end{array}$ & \multicolumn{6}{|c|}{$\geq 0,001 ; 5,135$} \\
\hline \multirow[t]{5}{*}{7} & $\begin{array}{l}\text { Переворот } \\
\text { вперед на дві } \\
\text { ноги } \\
\end{array}$ & $\bar{x}$ & 5,50 & 6,13 & $\begin{array}{l}\leq 0,05 \\
1,773\end{array}$ & 6,00 & 8,15 & $\begin{array}{l}\geq 0,001 \\
; \\
6,014\end{array}$ \\
\hline & & $\mathrm{S}$ & 1,29 & 1,15 & & 1,20 & 1,38 & \\
\hline & & $\mathrm{V}$ & 23,37 & 18,84 & & 20,00 & 16,88 & \\
\hline & & $\mathrm{p}, \mathrm{t}_{\text {розр }}$ (до) & \multicolumn{6}{|c|}{$\leq 0,05 ; 1,419$} \\
\hline & & $\begin{array}{ll}\mathrm{p}, & \mathrm{t}_{\text {розр }} \\
\text { (після) } & \end{array}$ & \multicolumn{6}{|c|}{$\geq 0,001 ; 5,662$} \\
\hline \multirow[t]{5}{*}{8} & $\begin{array}{ll}\text { Переворот } \\
\text { вперед } \\
\text { одну ногу }\end{array}$ & - & 4,79 & 5,58 & $\begin{array}{l}\leq 0,05 \\
1,699\end{array}$ & 5,19 & 8,31 & $\begin{array}{l}\geq 0,001 \\
; \\
8,794\end{array}$ \\
\hline & & $\mathrm{S}$ & 1,93 & 1,21 & & 1,50 & 1,01 & \\
\hline & & $\mathrm{V}$ & 40,35 & 21,72 & & 28,83 & 12,17 & \\
\hline & & $\mathrm{p}, \mathrm{t}_{\text {розр }}$ (до) & \multicolumn{6}{|c|}{$\leq 0,05 ; 0,815$} \\
\hline & & $\begin{array}{l}\mathrm{p}, \\
\text { (після) }\end{array}$ & \multicolumn{6}{|c|}{$\geq 0,001 ; 8,590$} \\
\hline \multirow[t]{5}{*}{9} & $\begin{array}{l}\text { Переворот } \\
\text { назад на одну } \\
\text { ногу }\end{array}$ & $\bar{x}$ & 4,79 & 5,25 & $\begin{array}{l}\leq 0,05 \\
0,780\end{array}$ & 5,19 & 7,92 & $\begin{array}{l}\geq 0,001 \\
; \\
5,342\end{array}$ \\
\hline & & $\mathrm{S}$ & 2,19 & 1,87 & & 2,32 & 1,20 & \\
\hline & & $\mathrm{V}$ & 45,63 & 35,63 & & 44,59 & 15,11 & \\
\hline & & $\mathrm{p}, \mathrm{t}_{\text {розр }}($ до) & \multicolumn{6}{|c|}{$\leq 0,05 ; 0,629$} \\
\hline & & $\begin{array}{ll}\mathrm{p}, & \mathrm{t}_{\text {розр }} \\
\text { (після) } & \\
\end{array}$ & \multicolumn{6}{|c|}{$\geq 0,001 ; 5,963$} \\
\hline \multirow[t]{5}{*}{10} & $\begin{array}{l}\text { “Темповий” } \\
\text { переворот } \\
\text { вперед }\end{array}$ & $\bar{x}$ & 3,13 & 3,88 & $\begin{array}{l}\leq 0,05 \\
1,070\end{array}$ & 3,65 & 7,50 & $\begin{array}{l}\geq 0,001 \\
; \\
7,261\end{array}$ \\
\hline & & $\mathrm{S}$ & 2,46 & 2,40 & & 2,38 & 1,27 & \\
\hline & & $\mathrm{V}$ & 78,56 & 61,97 & & 65,20 & 16,97 & \\
\hline & & $\mathrm{p}, \mathrm{t}_{\text {розр }}$ (до) & \multicolumn{6}{|c|}{$\leq 0,05 ; 0,772$} \\
\hline & & $\begin{array}{l}\mathrm{p}, \\
\text { (після) }\end{array}$ & $\geq 0,00$ & 6,590 & & & & \\
\hline
\end{tabular}


Аналіз результатів табличних даних 4 отриманих наприкінці педагогічного експерименту, дозволив встановити наступне:

- рівень акробатичної підготовленості, як у контрольній, так і у експериментальній групі став значно вищий. Так, у контрольній групі середньо арифметичний показник відповідає рівню вище середнього - 6,65 балів, а у експериментальній групі - високому рівню 8,52 бали;

- порівнюючи показники контрольної та експериментальної групи до та після педагогічного експерименту, можна зробити висновок, що у експериментальній групі у всіх тестах $€$ достовірність відмінностей

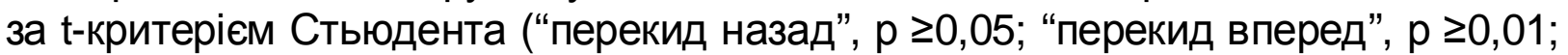
“стійка на руках", “переворот боком”, "рандат”, “гімнастичний міст”, “переворот вперед на дві ноги”, “переворот вперед на одну ногу”, “переворот назад на

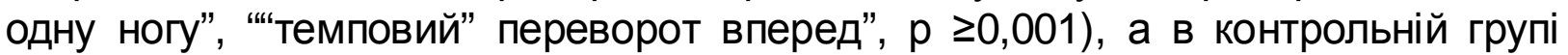
достовірність розбіжностей простежується лише у двох тестах: "стійка на руках", “переворот боком", $p \geq 0,05$ (рис. 4).
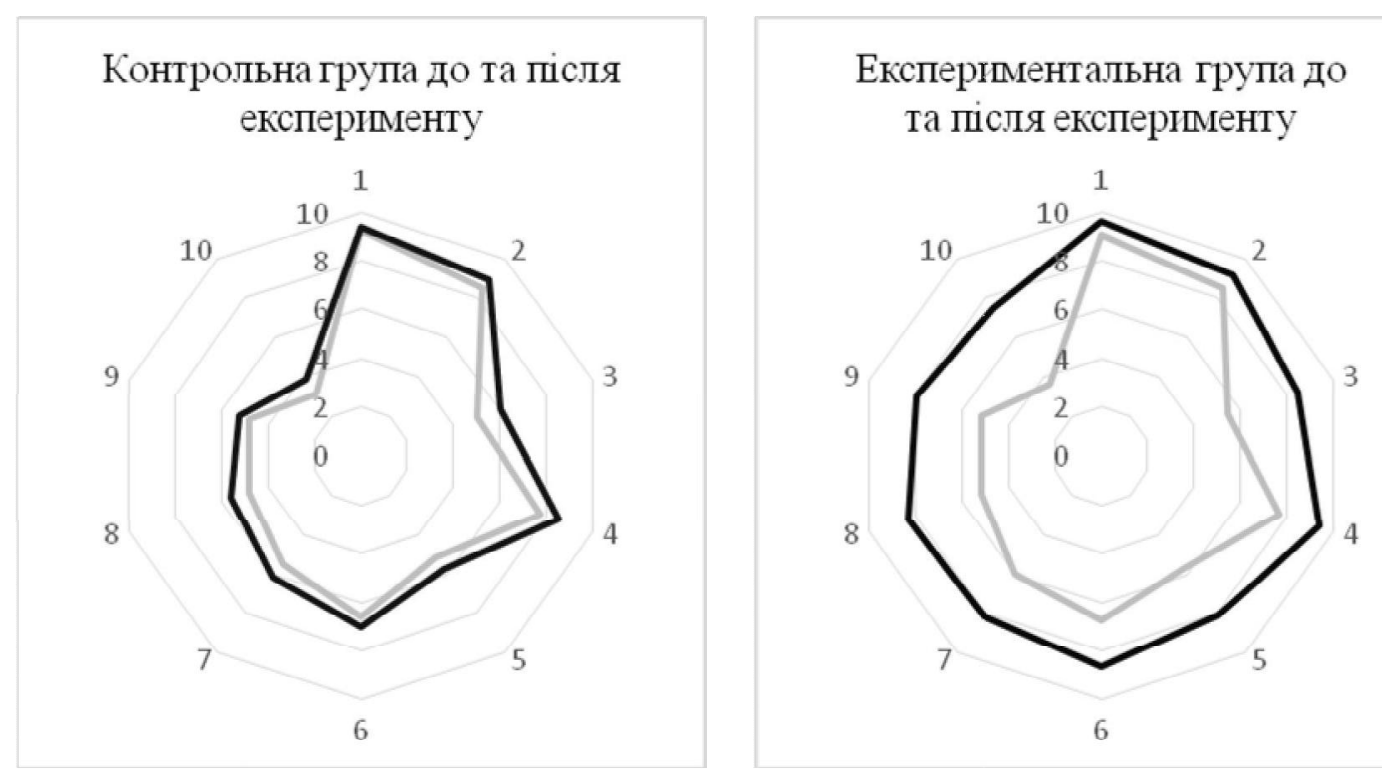

Рис. 4. Приріст показників з технічної підготовленості контрольної та експериментальної груп черлідирів-флаєрів наприкінці річного цฺиклу підготовки:

- до експерименту, - - після експерименту:

1 - “перекид вперед”; 2 - “перекид назад”; 3 - “стійка на руках"; 4 "переворот боком"; 5 - "рандат”; 6 - "гімнастичний міст”; 7 - переворот вперед на дві ноги; 8 - переворот вперед на одну ногу" 9 - переворот назад на одну ногу; 10 - ““"темповий” переворот вперед”

Аналізуючи показники контрольної та експериментальної групи до та після педагогічного експерименту робимо наступні висновки (рис. 5):

- на початку педагогічного експерименту між контрольною та експериментальною групами немає достовірної розбіжності показників за t-критерієм Стьюдента ( $\mathrm{p} \leq 0,05)$;

- наприкінці педагогічного експерименту достовірна розбіжность 
результатів за t-критерієм Стьюдента $€$ у всіх тестах, окрім тесту "перекид вперед" та тесту “перекид назад".

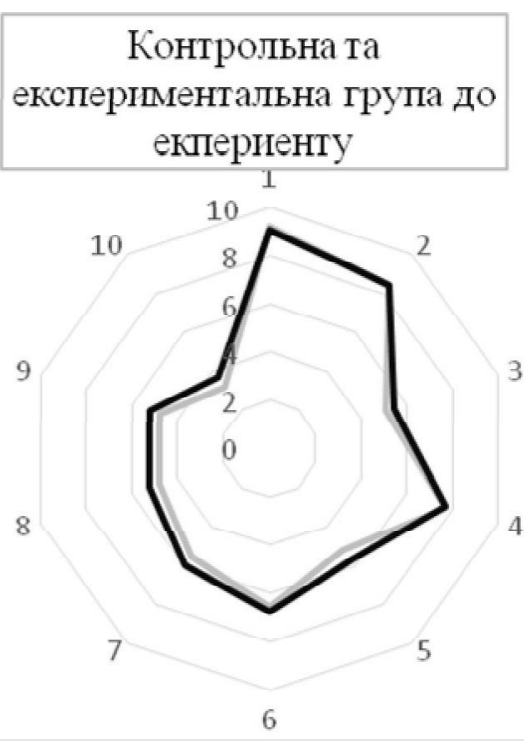

Контропьна та

експериментальна група піспя експерименту

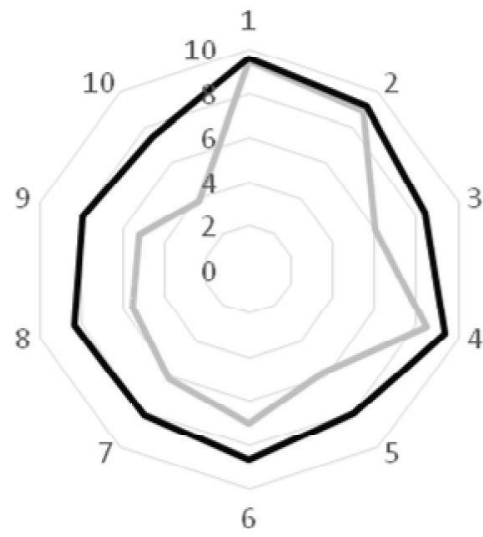

Рис. 5. Приріст показників з технічної підготовленості контрольної та експериментальної груп черлідирів-флаєрів наприкінці річного цииклу підготовки:

- контрольна група, - - експериментальна група:

1 - “перекид вперед"; 2 - “перекид назад”; 3 - "стійка на руках"; 4 -“ переворот боком"; 5 - "рандат"; 6 - "гімнастичний міст”; 7 - переворот вперед на дві ноги; 8 - переворот вперед на одну ногу" 9 - переворот назад на одну ногу; 10 - ““"темповий” переворот вперед”

На внутрішньогруповій вибірці відмінностей від результатів наприкінці педагогічного експерименту спостерігається у сильній однорідності показників в контрольній та експериментальній групах у таких тестах, як: "перекид вперед" ( $\mathrm{V}=7,62 \%$ та $\mathrm{V}=5,16 \%$ відповідно), “перекид назад" ( $\mathrm{V=8,04 \%}$ та V=10,10\% відповідно), “переворот в сторону (“Колесо”)" ( $\mathrm{V=10,97 \%}$ та 12,08\% відповідно), “Міст” (V=13,32\% та V=15,31\% відповідно). Отримані коефіцієнти варіації свідчать про однаковий рівень акробатичної підготовки черлідирів-бази на внутрішньогруповому рівні. Середня однорідність показників в контрольній та експериментальній групах є у таких тестах, як: "стійка на руках" (V=21,54\% та $V=17,5 \%$ відповідно), "Рандат" " ( $V=21,91 \%$ та $V=16,02 \%$ відповідно), "переворот вперед на дві ноги" (V=18,84\% та $V=16,88 \%$ відповідно), "переворот вперед на одну ногу" ( $\mathrm{V}=21,72 \%$ та $\mathrm{V}=12,17 \%$ відповідно). Так, отримані коефіцієнти варіації в окремих випадках свідчать про незначні розбіжності показників. У тестах “переворот назад на одну ногу" та "темповий переворот вперед" у контрольній групі слабка однорідність показників ( $V=35,63 \%$ та $V=61,97 \%$ відповідно), а в експериментальній групі у даних тестах $€$ сильна однорідність показників, де $(\mathrm{V}=15,11 \%$ та $\mathrm{V}=16,97 \%$ відповідно). 
Дискусія. Аналіз спеціальної наукової літератури показав, шо незалежно від того, що $є$ достатньо наукових робіт з вдосконалення окремих компонентів системи підготовки у складнокоординаційних видах спорту $[1,4,5,6,15,17]$, не достатньо уваги приділяється вивченню та вдосконаленню системи підготовки спортсменів-черлідирів. Це можна пояснити тим, що черлідинг $€$ молодим видом спорту, який претендує на включення його до програми Олімпійських ігор. В Україні черлідинг набув свого інтенсивного розвитку на початку XXI століття.

Як зазначають науковці $[2,9,12,18]$ рівень розвитку фрізичних якостей напряму впливає на процес навчання та вдосконалення технічної майстерності виконання змагальних вправ, тому сьогодні тренери акцентують увагу у навчально-тренувальному процесі на плануванні загальної та спеціальної фрізичної підготовленості. спортивної підготовки з урахуванням їх функцій, які виконують черлідири на гімнастичному килимі.

Висновки:

Дослідження рівня технічної підготовленості черлідирів-фрлаєрів визначався за підібраними нами контрольними тестами, які були об'єднані в чотири групи комплексних критеріїв: базові рухи черлідингу ("комплекс базових рухів" та "танцювальна зв'язка"), чер-стрибки (“Той-Тач", "Пайп" та "Навколо віту"), складність положень фрлаєра (“Основна стійка", “Стег”, “Ліберті", "Прапорець" та "Скорпіон"), технічне виконання акробатичних елементів (“перекид вперед”, “перекид назад”, “стійка на руках", “переворот боком”, "Рандат”, "гімнастичний міст", "переворот вперед на дві ноги", "переворот вперед на одну ногу", “переворот назад на одну ногу” ““темповий” переворот вперед").

Доведено, що на початку впровадження експериментальної методики контрольна та експериментальна групи на внутрішньогруповому рівні не мали достовірних відмінностей за t-критерієм Стьюдента $(p \geq 0,05)$., але після впровадження експериментальної методики рівень технічної підготовленості, як у контрольній, так і у експериментальній групах, став вищий.

Середньо арифметичний показник рівня технічної підготовленості черлідирів-фрлаєрів експериментальної групи у кожному комплексі тестів підвищився до високого рівня.

Перспективами подальших досліджень аналіз результатів етапного контролю оцінки рівня технічної підготовленості черлідирів-бази після впровадження експериментальної методики.

Використана література:

1. Бекетова А. Н. “Черлидинг”: Методические указания. Харьков, 2017. 19 с.

2. Боляк А. А. Чирлідинг : Правила змагань. Харків, 2005, 82 с.

3. Демідова О. М. Фізична підготовка танцюристів $15-16$ років на етапі спеціалізованої базової підготовки : дис. ... к.фіз.вих: 24.00 .01 / Дніпропетровський державний інститут фізичної культури і спорту. Дніпропетровськ, 2015. 230 с.

4. Долбишева Н. Г., Кидонь В. Закономірності взаємозв'язку технічної, фізичної підготовленості та функціонального стану спортсменок, які займаються естетичною гімнастикою. Фізична культура, спорт та здоров'я нащії : збір. наук. праць. Житомир : Видавець О. О. Свенок, 2017. Вип. 4 (23). C. 30-36. 
5. Долбишева Н., Кидонь В. Основні закономірності вдосконалення технічної підготовленості спортсменок, які займаються естетичною гімнастикою на етапі спеціалізованої базової підготовки. Молодіжний науковий вісник Східноєвропейського наиіонального університету імені Лесі Украйнки. Фізична культура і спорт / уклад. А. В. Цьось, А. І. Альошина. Луцьк, 2017. Вип. 27. С. 194-205.

6. Долбишева Н. Г., Михайліченко А. Г. Технічна та фізична підготовленість черлідирів-флаєрів на етапі попередньої базової підготовки. Спортивний вісник Придніпров'я. Дніпро, 2018 № 2. С. 22-26.

7. Луценко Л. С., Бодренкова И. А.Взаимосвязь показателей общей и специальной физической подготовленности спортсменов-черлидеров на этапе специализированной базовой подготовки. Физическое воспитание студентов. 2013. № 6. С. 43-49. doi:10.6084/m9.figshare.840502

8. Зинченко И. А., Луценко Л. С., Боляк А. А. Управление тренировочным процессом на основе моделирования показателей физической подготовленности спортсменов-черлидеров специализированного этапа подготовки. Слобожанкий научно-спортивный вестник. Харьков, 2010. № 2. C. 52.

9. Михайліенко А. Г. Технічна підготовка в навчально-тренувальному процесі юних спортсменівчерлідирів на етапі попередньої базової підготовки. Спортивний вісник Придніпров'я. Дніпро, 2018 № 1. C. 55-58.

10. Михайліенко А. Г. Методика вдосконалення технічної підготовки черлідирів на етапі попередньої базової підготовки. Наукові записи. Київ, 2019. № 142. С. 79-92.

11. Платонов В.Н. Система подготовки спортсменов в олимпийском спорте. Общая теория и ее практические приложения. Киев : Олимпийская литература, 2015. 808 с.

12. Самохина Е. А., Седих Н. В. Особенности организации занятий по черлидингу на этапе подготовки к соревнованиям детей 8-11 лет. Физическая культура и спорт. Харьков, 2017. С. 302315.

13. Спортивна акробатика. Навчальна програма для дитячо-юнацьких спортивних шкіл. Вінниця, $2010.92 \mathrm{c}$.

14. Тодорова В. Теоретико-методичні основ хореографічної підготовки в техніко-естетичних видах спорту (на метеріалі спортивної аеробіки) : монографія. Львів : ЛДУФК, 2018. 252 с.

15. Топол А. А. Комплексная оценка подготовленности квалифицированных спортсменок в художественной гимнастике: дисс. ... кан. физ. вис. : 24.00.01 / Национальный университет физического воспитания и спорта Украины. Киев, 2017. 232 с.

16. Cheppel R. Successful coaching for cheerleading. New York : Humon Kinetics, 1999. 364 p.

17. Human Kinetics. Coaching Youth Cheerleading (Coaching Youth Sports Series). Pom Headridge. 2009. $152 \mathrm{p}$.

\section{References:}

[1] Beketova A. N. "Cherliding": Metodicheskiye rekomendatsii. Khar'kov, 2017.19 str.

[2] Bolyak A. A. Cherliding: pravila Zmagana. Khar'kov, 2005, $82 \mathrm{~s}$.

[3] Demidova O. M. Fizichna Podgotovka tantsorov 15-16 dney na etoy spetsial'noy spetsial'noy trenirovke: diss. ... Kandidat nauk. vih: 24.00.01 / Dnepropetrovskiy gosudarstvennyy institut fizicheskoy kul'tury i sporta. Dnepropetrovsk, $2015.230 \mathrm{~s}$.

[4] Dolbisheva N. G., Kidon V. Zakon vzaimoobmena tekhniko-fizicheskoy podgotovki i funktsional'noy podgotovki sportsmenov, zanimayushchikhsya esteticheskoy gimnastikoy. Fizicheskaya kul'tura, sport $i$ zdorov'ye yavlyayutsya natsional'nymi: zbir. nauk. Chastey. Zhitomir: Vidavets O.O. ReathVenok, 2017. VIP. 4 (23). S. 30-36.

[5] Dolbisheva N., Kidon' V. Osnovopolagayushchim normativno-pravovym aktom podgotovitel'noy podgotovki sportsmenov, kotoryye zanimayutsya spetsial'nymi priyemami $\mathrm{v}$ oblasti spetsial'noy podgotovki. Molodezhnyy nauchnyy visnyk Skhidnoêvropeyskogo natsional'nogo universiteta im. Lesi Ukrainki. Fízichna kul'tura í sport / ukladka. A. V. TS'os', A. Í. Al'oshina. Luts'k, 2017. Vip. 27. S. 194205.

[6] Dolbisheva N. G., Mikhaylíchenko A. G. Tekhnichna ta fízichna pídgotovleníst' chernídirívív-flaêrív na popapí poperedn'oí bazovoí pídgotovki. Sportivnyy vísnik Pridníprov’ya. Dnípro, 2018 № 2. S. 22-26.

[7] Lutsenko L. S., Bodrenkova I. Attestaty obshchey i spetsial'noy fizicheskoy podgotovlennosti sportsmenov-cherliderov na stadii spetsializirovannoy finansovoy podgotovki. Fizicheskoye vospitaniye studentov. 2013. № 6. S. 43-49. DOI: 10,6084 / m9.figshare.840502 
[8] Zinchenko I. A., Lutsenko L. S., Bolyak A. A. Upravleniye trenirovochnym protsessom na osnove modelirovaniya pokazateley fizicheskoy podgotovlennosti sportsmenov-cherliderov spetsializirovannogo etapa podgotovki. Slobozhankiy nauchno-sportivnyy vestnik. Khar'kov, 2010. № 2. S. 52.

[9] Mikhaylíenko A. G. Tekhnicheskaya podgotovka v ramkakh vsemirno-trendovogo protsessa yunykh sportsmenov-cherlidirov v ramkakh bazovoy podgotovki. Sportivnyy vísnik Pridníprov'ya. Dnípro, 2018 № 1. S. 55-58.

[10] Mikhaylíenko A. G. Metodika dvukhstoronney tekhnicheskoy podgotovki na stadii razrabotki. Naukoví zapisi. Kiyev, 2019 № 142. S. 79-92.

[11] Platonov V. N. Sistema podgotovki sportsmenov v olimpiyskom sporte. Obshchaya teoriya i yeye prakticheskiye prilozheniya. Kiyev: Olimpiyskaya literatura, 2015. $808 \mathrm{~s}$.

[12] Samokhina Ye. A., Sedikh N. V. Osobennosti organizatsii zanyatiy po cherlidingu na etape podgotovki k sorevnovaniyam detey 8-11 let. Fizicheskaya kul'tura i sport. Khar'kov, 2017. S. 302-315.

[13] Sportivna akrobatika. Navchal'na programa dlya dityacho-yunats'kikh sportivnykh shkíl. Vinnitsa, 2010.92 s.

[14] Todorova V. Teoretiko-metodicheskiye osnovy khoreograficheskoy podgotovki v tekhniko-sportivnykh distsiplinakh (monografiya): monograficheskaya. L'vív: LDUFK, 2018. $252 \mathrm{~s}$.

[15] Topol A. A. Kompleksnaya otsenka podgotovlennosti kvalifitsirovannykh sportsmenok v khudozhestvennoy gimnastike : diss. ... kan. fiz. vis. : 24.00.01 / Natsional'nyy universitet otkrytogo vospitaniya i sporta Ukrainy. Kiyev, 2017. 232 s.

[16] Cheppel' R. Uspeshnaya trenirovka po cherlidingu. N'yu-York : Humon Kinetics, 1999. 364 s.

[17] Kinetika cheloveka. Trenirovka yunosheskoy cherliding (Coaching Youth Sports Series). Pom Khedridzh. 2009. 152 s.

БУзовеРЯ А. Г. Анализ результатов этапного контроля оценки уровня технической подготовленности черлидиров-флаеров после внедрения экспериментальной методики.

Исследование уровня технической подготовленности черлидиров-флаеров определялся по подобранными нами контрольным тестам, которые были объединены в четыре группь комплексных критериев: базовые движения черлидинга, чер-прыжки, сложность положений флаера, техническое исполнение акробатических элементов. В свою очередь данные комплексы содержали в себе следующие тесты: "комплекс базовых движений” и "танцевальная связка"; "Тот Тач”, “Пайп” и “Вокруг виту”; “Основная стойка”, “Стег”, “Либерти”, “Флажок” и "Скорпион”; “кувырок вперед”, “кувырок назад”, “стойка на руках”, “переворот боком”, "Рандат”, “гимнастический мост”, “переворот вперед на две ноги”, “переворот вперед на одну ногу”, “переворот назад на одну ногу”, “"темповый” переворот вперед”.

По результатам анализа технической подготовленности черлидиров-флаеров 9-10 лет в начале внедрения экспериментальной методики, необходимо отметить следующее, что контрольная и экспериментальная группы на внутригрупповом уровне не имели достоверных отличий по t-критерию Стьюдента $(p \geq 0,05)$., Но после внедрение экспериментальной методики уровень технической подготовленности, как в контрольной, так и в экспериментальной группах стал выше. В комплексе тестов “базовых движений черлидинга" в контрольной группе средние показатели остались на уровне выше среднего (от 4,04 до 4,21), a в экспериментальной группе - уровень оценок перешел от выше среднего на высокий (от 4,58 до 4, 65), комплекс тестов "Че-прыжков" экспериментальной группы повысился до высокого уровня ("Тот Тач” - 4,5, “Пайп” - 4.62, “Вокруг света" - 4,54) прирост показателей в комплексе тестов "сложность положений флаера" в экспериментальной группе больше, нежели в контрольной во всех тестах кроме контрольного теста - положение флаера "Основная стойка"; средне арифметический показатель выполнения акробатических элементов в контрольной группе соответствует уровню выше среднего - 6,65 баллов, а в экспериментальной группе - высокому уровню 8,52 балла.

Ключевые слова: черлидин, черлидиры-база, техническая подготовка, техническая подготовленность, спещиальная техническая подготовка, этап предварительной базовой подготовки. 
BUZOVERYA A. G. Analysis of the results of the stage control of the evaluation of the technical preparation level of the cheerlidirs-flyers after the implementation of the experimental.

The study of the level of technical readiness of flyer cheerleaders was determined by the control tests we selected, which were combined into four groups of complex criteria: basic cheerleading movements, cheer-jumps, complexity of flyer positions, technical execution of acrobatic elements.

In turn, these complexes contained the following tests: "basic movements" and "dance communication"; "To-Touch", "Pipe" and "Around the World"; "Main Stand", "Steg", "Liberty", "Flag", and "Scorpio"; "Forward", "overturn", "handstand", "sideways", "Randat", "gymnastic", "two-legged", "one-legged", "back-to-back one leg”, "'tempo" revolution forward".

According to the analysis of technical readiness of flyer 9-10 years at the beginning of the experimental procedure, it should be noted that the control and experimental groups at the intragroup level had no significant differences on the Student's $t$-test $(p \geq 0.05)$, implementation of the experimental methodology, the level of technical readiness, both in the control and experimental groups, became higher. In the Cheerleading Basic Movement Tests, the control group remained above average (from 4.04 to 4.21), and in the experimental group, the level of grades went from above average to high (from 4.58 to 4, 65); the complex of "Cheer-jumps" tests of the experimental group increased to a high level ("To-Touch" - 4,5; "Pipe" - 4.62; "Around the World" - 4,54); the increase of indicators in the complex of tests "complexity of positions of the flyer" in the experimental group is greater, and than in the control in all tests except the control test - the position of the flyer "Main rack"; the arithmetic mean of acrobatic element performance in the control group corresponds to a level above the average of 6.65 points, and in the experimental group a high level of 8.52 points.

Keywords: cheerleading, cheerleading-base, technical training, technical readiness, special technical training, stage of preliminary basic training.

DOI: https://doi.org/10.31392/NZ-npu-145.2019.03

УДК 37.091.12:005.963.3]:502.13

Гармата О. М., Лазебна О. М., Бондаренко Л. І.

\section{ЕКОЛОГО-ЕКСКУСРІЙНА ДІЯЛЬНІСТЬ: МЕТОДИЧНИЙ АСПЕКТ}

Впровадження в Україні європейських стандартів життя і вихід на провідні позииії світу передбачає ряд реформ $і$ програм у всіх сферах суспільного буття. Серед інших вагомим чинником реалізачії Стратегії сталого розвитку $\epsilon$ спрямованість на збереження навколишнього середовища. Реалізація стратегії сталого розвитку потребує екологізації суспільства на всіх рівнях життєдіяльності людини. Об'єктиваџія зазначеного потребує осучасненого прочесуального забезпечення, що грунтується на можливостях методичних, технологічних досягнень суспільного розвитку. Використання еколого-екскурсійного інструментарію із застосуванням інформаційних методів дозволить оптимізувати становлення інтелектуально-когнітивної компоненти особистісного зростання людини, сприятиме формуванню екоцентричного вектору ї̈ світоглядних позицій.

Ключові слова: екологізація, екскурсійний метод, екскурсія, еколого-екскурсійна діяльність, методика проведення екскурсії, інформаційний метод. 